\title{
Elevated CSF1 serum concentration predicts poor overall survival in women with early breast cancer
}

\author{
Seyedhossein Aharinejad ${ }^{1,2}$, Mohamed Salama ${ }^{1,2}$, Patrick Paulus ${ }^{2}$, Karin Zins ${ }^{2}$, \\ Andreas Berger ${ }^{3}$ and Christian F Singer ${ }^{3}$ \\ Departments of ${ }^{1}$ Cardiac Surgery ${ }^{2}$ Cardiovascular Research ${ }^{3}$ Obstetrics and Gynecology, Medical University of \\ Vienna and Comprehensive Cancer Center, Waehringer Guertel 18-20, A-1090 Vienna, Austria
}

\author{
Correspondence \\ should be addressed \\ to S Aharinejad \\ Email \\ seyedhossein.aharinejad@ \\ meduniwien.ac.at
}

\begin{abstract}
Colony-stimulating factor 1 (CSF1) is a key regulator of mammary gland development, and a modulator of tissue macrophages. Expression of the CSF1 receptor gene C-FMS (CSF1R) is strongly associated with poor outcome in breast cancer and results in tumor cell invasiveness and pro-metastatic behavior in vitro. However, CSF1's role as a predictive factor in breast cancer remains unclear. We have prospectively measured circulating CSF1 using ELISA in 572 women with early breast cancer and in 688 women with benign breast lesions, and correlated these concentrations with overall survival (OS), nodal status, and other clinical and histological parameters. Serum CSF1 concentrations were significantly elevated in patients with early breast cancer when compared with those with benign tumors $(P<0.0001)$. Within breast cancer patients, CSF1 was higher in women with axillary lymph nodes $(P=0.03)$. Serum CSF1 correlated with tumor size $(P=0.002)$, age $(P<0.001)$, and Ki67 expression $(P=0.006)$. Log CSF1 serum concentrations were predictive of poor survival in both univariate (hazard ratio (HR): $3.77,95 \% \mathrm{Cl}: 1.65-8.65, P=0.002$ ) and multivariate analyses (HR: 3.1, 95\% Cl: 1.03-9.33, $P=0.04$ ). Post- but not premenopausal women with CSF1 serum concentrations $>873 \mathrm{pg} / \mathrm{ml}$ experienced a significantly poorer outcome $(P=0.004$ log-rank test). Serum CSF1 concentrations are elevated in women with malignant breast tumors. In early breast cancer, elevated serum CSF1 is associated with nodal involvement, and in postmenopausal women also with poor OS.
\end{abstract}

\author{
Key Words \\ - breast cancer \\ - diagnosis \\ - CSF1 \\ - survival \\ - lymph node metastasis
}

\section{Introduction}

Colony-stimulating factor 1 (CSF1) is produced by several cell lineages, and signaling through its proto-oncoprotein receptor c-fms (CSF1 receptor (CSF1R)) promotes the differentiation of myeloid progenitors into heterogeneous populations of monocytes, macrophages, dendritic cells, and bone-resorbing osteoclasts (Hume \& MacDonald 2012). The cytokine regulates the function and survival of macrophages, which act at multiple levels within the innate and adaptive immune systems (Ryan et al. 2001,
Pixley \& Stanley 2004, Hume \& MacDonald 2012). CSF1 also appears to have an important physiological role in mammary gland development as it is synthesized in ductal epithelium, and macrophages that are recruited by CSF1 promote both mammary ductal invasion during puberty and lobulo-alveolar differentiation during pregnancy (Pollard \& Hennighausen 1994, Gouon-Evans et al. 2000, Ryan et al. 2001). CSF1 is overexpressed in the mammary gland during pregnancy and lactation, suggesting the 
existence of a paracrine mode of action in the normal mammary gland (Sapi 2004).

In addition to its role in physiological breast development and function, enhanced recruitment of macrophages to mammary tumors (Liotta \& Kohn 2001, Kacinski 2002) and the poor prognosis associated with elevated number of tumor-associated macrophages (Bingle et al. 2002) also suggest a role of CSF1 in breast cancer (Pixley \& Stanley 2004). This assumption is supported by the observation that metastatic progression of mammary gland tumors is profoundly reduced in CSF1-deficient mice (Lin et al. 2001). Our own work points to the benefit of small interfering RNAs and antibodies directed against CSF1 in suppressing the growth and reversing chemoresistance of human mammary tumor xenografts in immunodeficient mice (Aharinejad et al. 2004, Paulus et al. 2006).

In the clinical setting, serum CSF1 concentrations are higher in breast, ovarian, and endometrial cancer patients when compared with healthy individuals (Kacinski et al. 1991, Kacinski 1995). A pilot study by Scholl et al. (1996) found that CSF1 was detectable in the serum of both early and metastatic breast cancer, and that increased CSF1 serum levels in women with early breast cancer were associated with a significantly shorter disease-free interval.

A nested case-control study within the Nurses' Heath Study which included 726 breast cancer patients provided the first evidence that elevated CSF1 concentrations are associated with a $33 \%$ increase in the risk of breast cancer in postmenopausal women, while it is associated with an $85 \%$ reduced risk in premenopausal women (Tamimi et al. 2008). The said retrospective study was performed in a serum bank obtained from women who had developed breast cancer during 1992 and 1998, and the results were published in 2008. We prospectively evaluated serum CSF1 concentrations, clinical, and histo-pathological parameters and 5-year overall survival (OS) in 1260 women with malignant and benign breast tumors between 2004 and 2009. Our results point to yet unknown roles of CSF1 in breast cancer.

\section{Subjects and methods}

\section{Patients}

Serum samples were prospectively obtained from 572 consecutive women with early breast cancer and in 688 consecutive women with benign breast tumors between 2004 and 2009. Cases had either been identified by opportunistic screening which was implemented on a national level during these years (benign and malignant breast tumors), or had been identified by women who specifically requested the removal of a radiologically un-suspicious breast lesion (benign breast tumors). Benign breast lesions included fibroadenomas, papillomas, complex sclerosing lesions, and pre-neoplastic lesions such as atypical ductal hyperplasia. None of the breast cancer patients had undergone local or systemic anticancer treatment before serum collection. This study has been approved by the Institutional Review Board of the Medical University of Vienna. All patients had given written informed consent to be enrolled in the study before blood sampling. The clinical and histopathological data were obtained from the patient's chart and OS was evaluated by the National Austrian Statistics Institute (Statistik Austria). All the data were coded and the key was broken at the end of the study.

\section{ELISA}

Serum samples were shock frozen in liquid $\mathrm{N}_{2}$ and stored at $-80^{\circ} \mathrm{C}$ until analysis. CSF1 ELISA assays (Quantikine, R\&D Systems, Minneapolis, MN, USA) were performed according to the manufacturer's protocol. In brief, $100 \mu \mathrm{l}$ assay diluent was added to the microplate wells, which were precoated with the monoclonal anti CSF1 antibody followed by the addition of patient's serum. The wells were then incubated for $2 \mathrm{~h}$ at room temperature, aspirated, and washed. CSF1 antibody conjugated to HRP (200 $\mu \mathrm{l})$ was added, and another $2 \mathrm{~h}$ incubation and three washes followed. Then, $200 \mu \mathrm{l}$ substrate solution (hydrogen peroxide, chromogen, and tetramethylbenzidine) was added to each well. The reaction was stopped after $30 \mathrm{~min}$ incubation by adding $50 \mu \mathrm{l} 1 \mathrm{M}$ sulfuric acid. The optical density was measured at $450 \mathrm{~nm}$ using an automated microplate reader (Thermo Fisher Scientific, Waltham, MA, USA).

\section{Statistical analysis}

All parameters were compared between patient groups by $\chi^{2}$-test, $t$-test, ANOVA (one-way ANOVA), and post hoc Tukey's test according to the scale of the variable. In case of skewed data, a nonparametric test (Mann-Whitney $U$ test) or one-way ANOVA; Tukey's test accomplished with $\log$ transformation were applied. To assess the correlation between CSF1 and other parameters, Spearman's rank correlation coefficients (rS) were computed. Survival rates were estimated using the Kaplan-Meier method. The prognostic value of CSF1 serum concentrations was

Published by Bioscientifica Ltd. 
studied using univariate and multiple Cox models. All $P$ values are shown as the results of two-sided tests. $P<0.05$ was considered statistically significant. All statistical analyses were performed by M Salama using SPSS software version 15.0 (SPSS, Inc.).

\section{Results}

\section{Clinical characteristics of the study cohort}

In this prospective study, a total of 1260 patients, 572 with breast cancer and 688 with a benign breast mass were included. Clinical and histopathological parameters are shown in Table 1. The median age of patients with breast cancer was 59 years and was significantly higher than the

Table 1 Patient and tumor characteristics.

\begin{tabular}{|c|c|c|c|}
\hline Characteristic & $\begin{array}{l}\text { Benign, } \\
n=688\end{array}$ & $\begin{array}{l}\text { Malignant, } \\
n=572\end{array}$ & $P$ value \\
\hline \multicolumn{4}{|l|}{ Age } \\
\hline $\begin{array}{l}\text { Median (years) } \\
\text { (range) }\end{array}$ & $45(15-83)$ & $59(28-91)$ & $<0.0001$ \\
\hline \multicolumn{4}{|l|}{ Tumor size } \\
\hline $\begin{array}{l}\text { Median }(\mathrm{cm}) \\
\text { (range) }\end{array}$ & $1.1(0.4-2.5)$ & $1.5(0.1-11)$ & 0.19 \\
\hline \multicolumn{4}{|l|}{ Menopausal status } \\
\hline Premenopausal & $504(73.3 \%)$ & $166(29.0 \%)$ & \\
\hline Postmenopausal & $184(26.7 \%)$ & $406(71.0 \%)$ & $<0.0001$ \\
\hline \multicolumn{4}{|l|}{ Nodal status } \\
\hline Negative & & $332(58.0 \%)$ & \\
\hline Positive & & $240(42.0 \%)$ & \\
\hline \multicolumn{4}{|l|}{ Tumor grade } \\
\hline G1 & & $123(21.5 \%)$ & \\
\hline G2 & & $268(46.9 \%)$ & \\
\hline $\mathrm{G} 3$ & & $179(31.3 \%)$ & \\
\hline Unknown & & $2(0.3 \%)$ & \\
\hline \multicolumn{4}{|l|}{ Estrogen receptor } \\
\hline Negative & & $130(22.7 \%)$ & \\
\hline Positive & & $416(72.7 \%)$ & \\
\hline Unknown & & $26(4.6 \%)$ & \\
\hline \multicolumn{4}{|l|}{$\begin{array}{l}\text { Progesterone } \\
\text { receptor }\end{array}$} \\
\hline Negative & & $266(46.5 \%)$ & \\
\hline Positive & & $280(49.0 \%)$ & \\
\hline Unknown & & $26(4.5)$ & \\
\hline \multicolumn{4}{|l|}{ HER2 } \\
\hline Negative & & $464(81.1 \%)$ & \\
\hline High & & $81(14.2 \%)$ & \\
\hline Unknown & & $27(4.7 \%)$ & \\
\hline \multicolumn{4}{|l|}{ Ki67, $n=511$} \\
\hline$<20$ & & $237(46.4 \%)$ & \\
\hline$\geq 20$ & & $274(53.6 \%)$ & \\
\hline \multicolumn{4}{|l|}{$\mathrm{p} \overline{53}, n=536$} \\
\hline Negative & & $411(76.7 \%)$ & \\
\hline Positive & & $125(23.3 \%)$ & \\
\hline \multicolumn{4}{|l|}{ Adjuvant therapy } \\
\hline Endocrine therapy & & $304(53.1 \%)$ & \\
\hline Chemotherapy & & $208(36.4 \%)$ & \\
\hline Local irradiation & & $403(70.5 \%)$ & \\
\hline
\end{tabular}

http://erc.endocrinology-journals.org DOI: 10.1530/ERC-13-0198
(C) 2013 Society for Endocrinology Printed in Great Britain

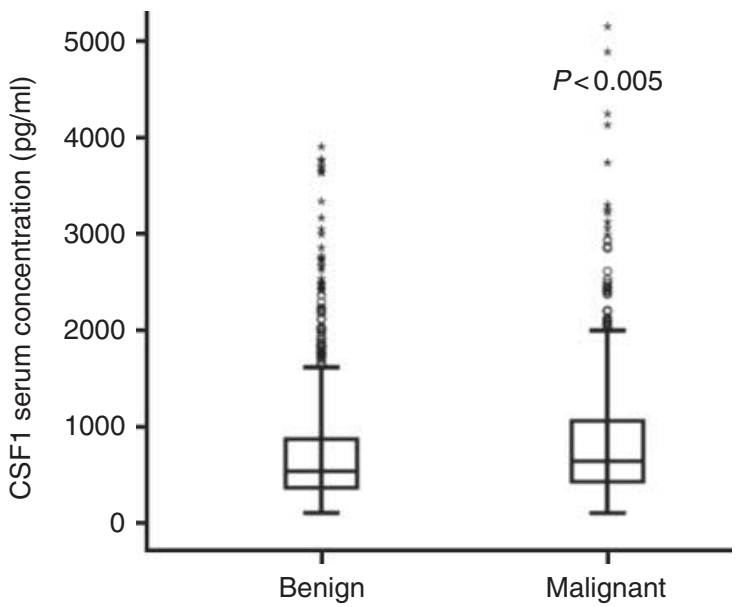

Figure 1

Box blot depicts CSF1 serum concentrations in patients with benign breast tumors and with early breast cancer.

median age of 45 years in patients with a benign breast mass $(P<0.0001)$. Consequently, breast cancer in our patient cohort was more frequently associated with postmenopausal status $(P<0.0001)$, while benign breast tumors were more common in premenopausal women $(P<0.0001)$. Of those patients who were diagnosed with breast cancer, 53\% received endocrine therapy, $36 \%$ had chemotherapy, and more than $70 \%$ were irradiated (Table 1).

\section{CSF1 serum concentrations in benign and malignant tumors}

The mean circulating CSF1 concentration was 889.0 $\pm 801 \mathrm{pg} / \mathrm{ml}$ in patients with breast cancer and was significantly higher than in those patients with benign breast lesions $(772.7 \pm 677 \mathrm{pg} / \mathrm{ml})(P<0.005$; Fig. 1$)$. No difference was observed in CSF1 serum levels when benign breast tumors (i.e., fibroasenomas and papillomas) were compared with other benign conditions such as complex sclerosing lesions or atypical ductal hyperplasia (data not shown).

Within the 572 patients with invasive breast cancer and concomitant lymph node metastasis, the mean serum CSF1 concentrations were $956.2 \pm 983 \mathrm{pg} / \mathrm{ml}$ and significantly higher than in those patients without lymph node involvement (805.9 $\pm 609, P=0.03$; Fig. 2). Also patients with N3 lymph node status had significantly higher serum CSF1 concentrations when compared with those with NO $(P=0.03)$ and N1 ( $P=0.04$; data not shown).

Published by Bioscientifica Ltd. 


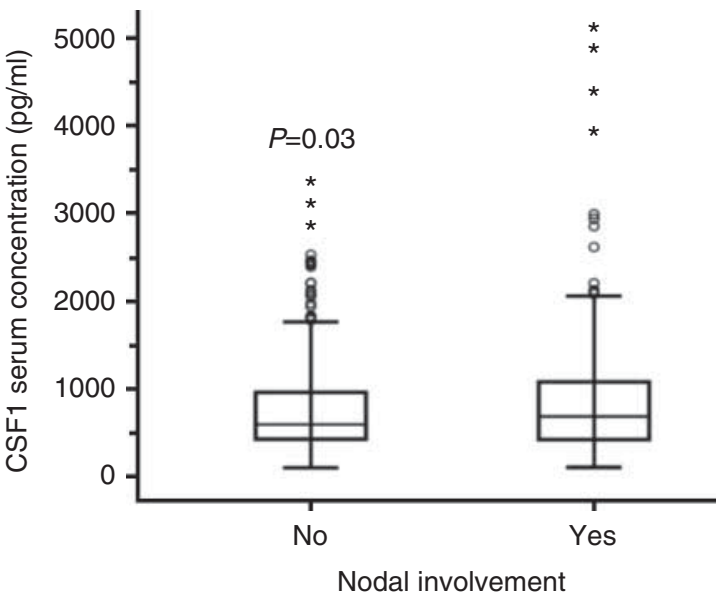

Figure 2

Box blot depicts CSF1 serum concentrations in patients without (no) or with (yes) nodal involvement.

\section{Serum CSF1 and clinically relevant parameters}

In Spearman's $\rho$ test, circulating CSF1 correlated weakly but significantly with tumor size $(r=0.48, P=0.002)$, age $(r=0.157, P<0.0001)$, and Ki67 expression levels $(r=0.119$, $P=0.006)$. There was, however, no statistically significant correlation with grading or nodal status (Table 2). Tumor size correlated weakly with nodal status $(r=0.122$, $P=0.015)$ and Ki67 expression level $(r=0.176, P=0.001)$. There was also a significant correlation between age and grading $(r=0.097, P=0.025)$, and between grading and Ki67 expression $(r=0.564, P<0.0001)$.

\section{CSF1 serum concentrations and OS}

To evaluate the effect of CSF1 serum concentrations on survival, patients were dichotomized according to their median serum CSF1 concentration. The median serum concentration in breast cancer patients was $873 \mathrm{pg} / \mathrm{ml}$ and was selected as a cutoff because it classified half of the breast cancer patients into high and low CSF1 concentration groups. At a median follow-up of 5.2 years, 62 of 572 (12\%) of patients had died (33 patients with low CSF1 $(<873 \mathrm{pg} / \mathrm{ml})$ and 29 with high CSF1 $(>873 \mathrm{pg} / \mathrm{ml})$ serum concentrations). Age (hazard ratio (HR) for death, 1.03; 95\% CI: 1.01-1.05, $P=0.007$ ), tumor size (HR for death, 1.02; 95\% CI: 1.01-1.04, $P=0.001$ ), nodal status (HR for death 1.91; 95\% CI: $1.08-3.40, P=0.02$ ), tumor grade (HR for death $1.97 ; 95 \%$ CI: $1.32-2.93, P=0.001)$, and $\log$ CSF1 serum concentrations (HR for death 3.77; 95\% CI: $1.65-$ $8.65, P=0.002)$ were significantly associated with breast cancer-specific survival in univariate analysis as well. The independent effect of CSF1 serum concentration on OS was assessed by multivariate Cox proportional hazard models adjusted for age, tumor size, nodal status, and tumor grade. In these multivariate analyses, logCSF1 serum concentrations remained significantly associated with OS (adjusted HR for relapse 3.10; 95\% CI: 1.03-9.33) (Table 3). Kaplan-Meier estimates for OS showed a significantly poorer outcome if CSF1 concentrations were higher than the median CSF1 concentration of $873 \mathrm{pg} / \mathrm{ml}$ in our study population $(P=0.02$, log-rank test; Fig. 3). When including the menopausal status into the analyses, it turned out that the poorer outcome in patients with CSF1 concentrations $>873 \mathrm{pg} / \mathrm{ml}$ was confined to postmenopausal women $(P=0.004)$, while no such effect was observed in premenopausal women with early breast cancer $(P=0.61)$ (Fig. 4).

\section{Discussion}

We have measured CSF1 serum concentrations in 1260 prospectively collected samples from women with benign and malignant breast lesions and correlated them with established clinically relevant parameters and OS. To our knowledge, this is the first prospective study, which

Table 2 Correlation between CSF1 serum concentrations and tumor parameters (Spearman's $\rho$ test).

\begin{tabular}{|c|c|c|c|c|c|}
\hline & Tumor size $(\mathrm{cm})$ & Age & Grading & Nodal status & Ki67 \\
\hline CSF1 (pg/ml) & $\begin{array}{l}r=0.148 \\
P=0.002\end{array}$ & $\begin{array}{l}r=0.157 \\
P<0.0001\end{array}$ & NS & NS & $\begin{array}{l}r=-0.119 \\
P=0.006\end{array}$ \\
\hline Tumor size & & & $r=0.193$ & $r=0.122$ & $r=0.176$ \\
\hline Age & NS & NS & $\begin{array}{l}P<0.0001 \\
r=-0.097\end{array}$ & $P=0.015$ & $P=0.001$ \\
\hline Grading & NS & NS & $P=0.025$ & NS & $\begin{array}{l}\text { NS } \\
r=0.564\end{array}$ \\
\hline Nodal status & NS & NS & NS & NS & $P<0.0001$ \\
\hline & NS & NS & NS & NS & NS \\
\hline
\end{tabular}

http://erc.endocrinology-journals.org DOI: 10.1530/ERC-13-0198
(C) 2013 Society for Endocrinology Printed in Great Britain
Published by Bioscientifica Ltd 
Table 3 Uni- and multivariate Cox proportional hazard models for overall survival.

\begin{tabular}{|c|c|c|c|}
\hline \multirow[b]{2}{*}{ Variable } & \multicolumn{3}{|c|}{ Univariate } \\
\hline & $\begin{array}{l}\text { HR for overall } \\
\text { survival }\end{array}$ & $95 \% \mathrm{Cl}$ & $P$ value \\
\hline Age & 1.03 & $1.01-1.05$ & 0.007 \\
\hline Tumor size & 1.02 & $1.01-1.04$ & 0.001 \\
\hline Nodal status & 1.91 & $1.08-3.4$ & 0.02 \\
\hline Tumor grade & 1.97 & $1.32-2.93$ & 0.001 \\
\hline Log. CSF1 & 3.77 & $1.65-8.65$ & 0.002 \\
\hline
\end{tabular}

\begin{tabular}{|c|c|c|}
\hline \multicolumn{3}{|c|}{ Multivariate } \\
\hline $\begin{array}{l}\text { HR for overall } \\
\text { survival }\end{array}$ & $95 \% \mathrm{Cl}$ & $P$ value \\
\hline 1.03 & $0.99-1.06$ & 0.07 \\
\hline 1.02 & $1.01-1.04$ & 0.004 \\
\hline 1.27 & $0.64-2.49$ & 0.49 \\
\hline 1.96 & $1.21-3.16$ & 0.006 \\
\hline 3.1 & $1.03-9.33$ & 0.04 \\
\hline
\end{tabular}

analyzes the clinical relevance of CSF1 in early breast cancer. The results of an earlier nested case-control study pointed to an inverse correlation between serum CSF1 concentrations and the subsequent risk for breast cancer in premenopausal women, while a positive correlation was found in postmenopausal women (Tamimi et al. 2008). Our results confirm the observations of a worse outcome in postmenopausal women with elevated serum CSF1 concentrations. The increase in systemic CSF1 levels, which we found in women with malignant breast tumors and in those with nodal positive breast cancer is, however, novel and suggests a direct involvement of CSF1 in tumor progression and malignant behavior.

At tissue level, CSF1R expression has been reported to be a strong predictor of poor outcome in nonmetastatic breast cancer and to be more frequently expressed in patients with nodal involvement (Kluger et al. 2004). A direct correlation between tissue array results of CSF1R and the serum concentrations of its ligand CSF1 has never been conducted (Kluger et al. 2004). The mode of action of CSF1 through CSF1R, however, justifies the assumption that serum concentrations of the ligand itself might have a prognostic significance in breast cancer (Hamilton 1997). The fact that tumor cells synthesize CSF1 in quantities high enough to be readily detected at tissue level and the evidence suggesting significantly elevated levels of CSF1 in serum and ascites of patients with breast, ovarian, and endometrial cancer (Chambers et al. 1997, Kacinski 1997, Maher et al. 1998) strongly suggest the functional relevance of the CSF1/CSF1R system. Finally, serum CSF1 in patients with terminal breast cancer has been reported to be more than tenfold higher than levels measured in healthy women, a finding that correlated well to increased CSF1 expression seen at sites of metastatic recurrence in another study (Kacinski et al. 1991, McDermott et al. 2002).

Experimental breast cancer models underscore the pathophysiological role of CSF1 in solid tumors. We have previously shown that CSF1 blockade by antisense nucleotides and small interfering RNAs suppresses growth of human mammary tumor xenografts in mice (Aharinejad et al. 2004). Furthermore, the targeting of CSF1 in primary breast cancer xenografts in the MMTV PyMT transgenic mouse model results in delayed tumor progression to metastasis, while overexpression of CSF1 in xenografts enhances tumor development (Lin et al. 2001). Although the exact biological mechanism by which CSF1 renders tumors more aggressive remains largely unknown, we and others have shown that CSF1 contributes to tumorigenesis and angiogenesis through stimulation of the expression of the macrophage-specific matrix metalloprotease (MMP)-12 as well as the expression of MMP2, MMP9, and uPA (Wang et al. 1988, Talkhoud et al. 1991, Nowicki et al. 1996, Frandsen et al. 2001, Ha et al. 2001, Aharinejad et al. 2004, Paulus et al. 2006).

Another mechanism by which CSF1 might contribute to a prometastatic behavior is through the activation of the immune system. Tumor-expressed CSF1 is able to

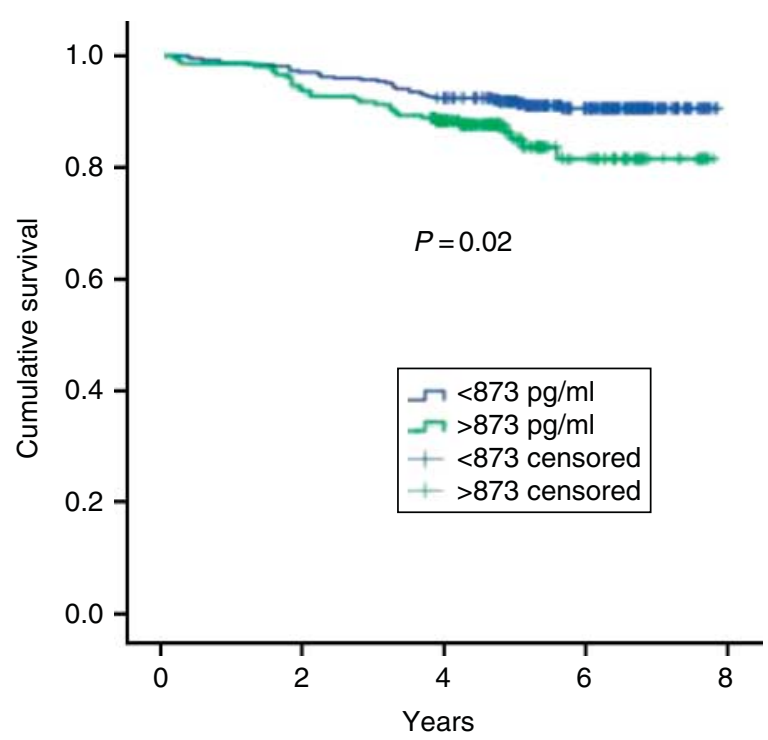

Figure 3

Cumulative overall survival (OS) in patients with CSF1 serum concentrations above (green) or below (blue) a cutoff of $873 \mathrm{pg} / \mathrm{ml}$.

Published by Bioscientifica Ltd 

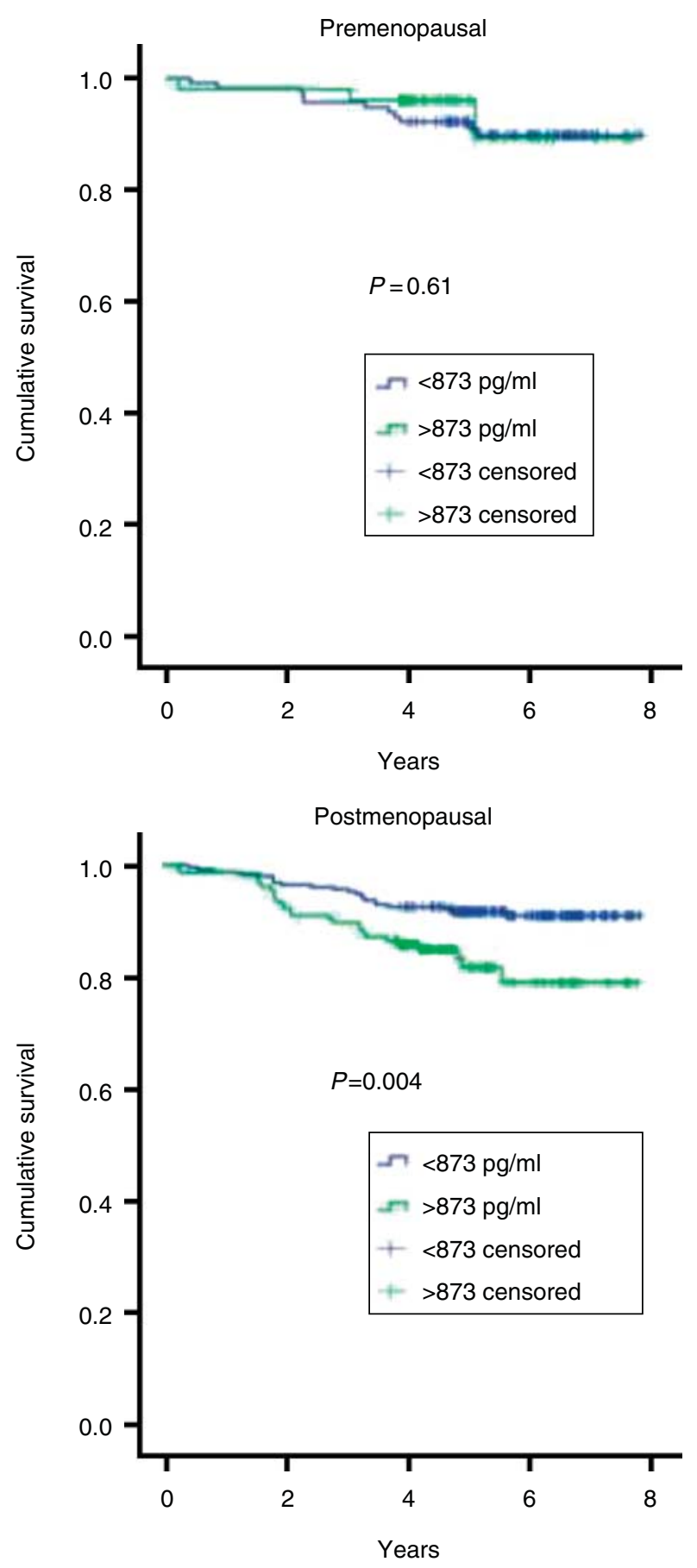

Figure 4

Cumulative overall survival (OS) in premenopausal (top panel) and postmenopausal (bottom panel) patients with CSF1 serum concentrations above (green) or below (blue) a cutoff of $873 \mathrm{pg} / \mathrm{ml}$.

recruit and activate macrophages that in turn release cytokines that enhance tumor cell growth in vitro and in vivo (Chambers et al. 1995). The existence of such a paracrine loop mechanism has already been demonstrated for CSF1/epidermal growth factor (Wyckoff et al. 2004, Goswami et al. 2005).

Activation of the CSF1/CSF1R system results in a dramatic stimulation of cellular invasiveness via a uPAdependent pathway in vitro. While such a mechanism might be essential during normal mammary gland development to allow ductal outgrowth by local matrix remodeling, the same principle would result in increased local invasion in malignant tumors. At least in ovarian cancer cell lines, the possibility of a uPA-mediated stimulation of invasion by CSF1 has already been demonstrated in vitro (Talkhoud et al. 1991).

Taken together, the results of the present prospective study show that in early breast cancer patients, elevated serum CSF1 is associated with increased tumor size, enhanced tumor cell proliferation, and nodal invasion. In postmenopausal women, CSF1 has a significant and clinically relevant role in predicting OS. Circulating CSF1 might be useful as a prognostic factor in breast cancer.

\section{Declaration of interest}

The authors declare that there is no conflict of interest that could be perceived as prejudicing the impartiality of the research reported.

\section{Funding}

This study was supported by a grant number 07053 from the Mayor of Vienna to S Aharinejad.

\section{Acknowledgements}

The authors thank Daniela Muhr for help with chart reviews, and the National Austrian Statistics Institute (Statistik Austria) for the evaluation of survival data. We would also like to acknowledge the technical assistance of Friederike Schramm.

\section{References}

Aharinejad S, Paulus P, Sioud M, Hofmann M, Zins K, Schäfer R, Stanley ER \& Abraham D 2004 Colony-stimulating factor-1 blockade by antisense oligonucleotides and small interfering RNAs suppresses growth of human mammary tumor xenografts in mice. Cancer Research 64 5378-5384. (doi:10.1158/0008-5472.CAN-04-0961)

Bingle L, Brown NJ \& Lewis CE 2002 The role of tumor-associated macrophages in tumor progression: implications for new anticancer therapies. Journal of Pathology 196 254-265. (doi:10.1002/path.1027)

Chambers SK, Wang Y, Gertz RE \& Kacinski BM 1995 Macrophage colonystimulating factor mediates invasion of ovarian cancer cells through urokinase. Cancer Research 55 1578-1585.

Chambers SK, Kacinski BM, Ivins CM \& Carcangiu ML 1997 Overexpression of epithelial macrophage colony-stimulating factor (CSF-1) and CSF-1 receptor: a poor prognostic factor in epithelial ovarian cancer, contrasted with a protective effect of stromal CSF-1. Clinical Cancer Research 3 999-1007. 
Frandsen TL, Holst-Hansen C, Nielsen BS, Christensen IJ, Nyengaard JR, Carmeliet P \& Brünner N 2001 Direct evidence of the importance of stromal urokinase plasminogen activator (uPA) in the growth of an experimental human breast cancer using a combined uPA genedisrupted and immunodeficient xenograft model. Cancer Research 61 532-537.

Goswami S, Sahai E, Wyckoff JB, Cammer M, Cox D, Pixley FJ, Stanley ER, Segall JE \& Condeelis JS 2005 Macrophages promote the invasion of breast carcinoma cells via a colony-stimulating factor-1/epidermal growth factor paracrine loop. Cancer Research 65 5278-5283. (doi:10.1158/0008-5472.CAN-04-1853)

Gouon-Evans V, Rothenberg ME \& Pollard JW 2000 Postnatal mammary gland development requires macrophages and eosinophils. Development 127 2269-2282.

Ha HY, Moon HB, Nam MS, Lee JW, Ryoo ZY, Lee TH, Lee KK, So BJ, Sato H, Seiki M et al. 2001 Overexpression of membrane-type matrix metalloproteinase-1 gene induces mammary gland abnormalities and adenocarcinoma in transgenic mice. Cancer Research 61 984-990.

Hamilton JA 1997 CSF-1 signal transduction. Journal of Leukocyte Biology 62 $145-155$.

Hume DA \& MacDonald KB 2012 Therapeutic applications of macrophage colony-stimulating factor-1 (CSF-1) and antagonists of CSF-1 receptor (CSF-1R) signaling. Blood 23 1810-1820. (doi:10.1182/blood-2011-09379214)

Kacinski BM 1995 CSF-1 and its receptor in ovarian, endometrial and breast cancer. Annals of Medicine 27 79-85. (doi:10.3109/ 07853899509031941)

Kacinski BM 1997 CSF-1 and its receptor in breast carcinomas and neoplasms of the female reproductive tract. Molecular Reproduction and Development 46 71-74. (doi:10.1002/(SICI)1098-2795(199701) 46:1 < 71::AID-MRD11 > 3.0.CO;2-6)

Kacinski B 2002 Expression of CSF-1 and its receptor CSF-1R in nonhematopoietic neoplasms. Cancer Treatment and Research 107 285-292.

Kacinski BM, Scata KA, Carter D, Yee LD, Sapi E, King BL, Chambers SK, Jones MA, Pirro MH, Stanley ER et al. 1991 FMS (CSF-1 receptor) and CSF-1 transcripts and protein are expressed by human breast carcinomas in vivo and in vitro. Oncogene 6 941-952.

Kluger HM, Dolled-Filhart M, Rodov S, Kacinski BM, Camp RL \& Rimm DL 2004 Macrophage colony-stimulating factor- 1 receptor expression is associated with poor outcome in breast cancer by large cohort tissue microarray analysis. Clinical Cancer Research 10 173-177. (doi:10.1158/ 1078-0432.CCR-0699-3)

Lin EY, Nguyen AV, Russel RG \& Pollard JW 2001 Colony-stimulating factor-1 promotes progression of mammary tumors to malignancy. Journal of Experimental Medicine 193 727-739. (doi:10.1084/jem. 193.6.727)

Liotta LA \& Kohn EC 2001 The microenvironment of the tumor-host interface. Nature $\mathbf{4 1 1}$ 375-379. (doi:10.1038/35077241)

Maher MG, Sapi E, Turner BC, Gumbs A, Perotta PL, Carter D, Kacinski BM \& Haffty BG 1998 Prognostic significance of colony stimulating factor receptor expression in ipsilateral breast cancer recurrence. Clinical Cancer Research 4 1851-1856.

McDermott RS, Deneux L, Mosseri V, Vedrenne J, Clough K, Fourquet A, Rodriguez J, Cosset JM, Sastre X, Beuzeboc P et al. 2002 Circulating macrophage colony stimulating factor as a marker of tumour progression. European Cytokine Network 13 121-127.

Nowicki A, Szenajch J, Ostrowska G, Wojtowicz A, Wojtowicz K, Kruszewski AA, Maruszynski M, Aukerman SL \& Wiktor-Jedrejczak W 1996 Impaired tumor growth in colony-stimulating factor (CSF-1)deficient, macrophage-deficient op/op mouse: evidence for a role of CSF-1 dependent macrophages in formation of tumor stroma. International Journal of Cancer 65 112-119. (doi:10.1002/(SICI)10970215(19960103)65:1 <112::AID-IJC19>3.0.CO;2-I)

Paulus P, Stanley ER, Schäfer R, Abraham D \& Aharinejad S 2006 Colony-stimulating factor-1 antibody reverses chemoresistance in human MCF-7 breast cancer xenografts. Cancer Research 66 4349-4356. (doi:10.1158/0008-5472.CAN-05-3523)

Pixley FJ \& Stanley ER 2004 CSF-1 regulation of the wandering macrophage: complexity in action. Trends in Cell Biology 14 628-638. (doi:10.1016/j.tcb.2004.09.016)

Pollard JW \& Hennighausen L 1994 Colony stimulating factor 1 is required for mammary gland development during pregnancy. PNAS 91 9312-9316. (doi:10.1073/pnas.91.20.9312)

Ryan GR, Dai XM, Dominguez MG, Tong W, Chuan F, Chisholm O, Russell RG, Pollard JW \& Stanley ER 2001 Rescue of the colonystimulating factor 1 (CSF-1)-nullizygous mouse (Csf1(op)/Csf1(op)) phenotype with a CSF-1 transgene and identification of sites of local CSF-1 synthesis. Blood 98 74-84. (doi:10.1182/blood.V98.1.74)

Sapi E 2004 The role of CSF-1 in normal physiology of mammary gland and breast cancer: an update. Experimental Biology and Medicine 229 1-11.

Scholl SM, Lidereau R, de la Rochefordiere A, Le-Nir CC, Mosseri V, Nougues C, Pouillart P \& Stanley FR 1996 Circulating levels of the macrophage colony stimulating factor CSF-1 in primary and metastatic breast cancer patients. A pilot study. Breast Cancer Research and Treatment 39 275-283. (doi:10.1007/BF01806155)

Talkhoud RS, Chin JR, Unemori EN, Werb Z \& Bissell MJ 1991 Proteinases of the mammary gland: developmental regulation in vivo and vectorial secretion in culture. Development 112 439-449.

Tamimi RM, Brugge JS, Freedman ML, Miron A, Iglehart JD, Colditz GA \& Hankinson SE 2008 Circulating colony stimulating factor-1 and breast cancer risk. Cancer Research 68 18-21. (doi:10.1158/0008-5472.CAN07-3234)

Wang JM, Griffin JD, Rambaldi A, Chen ZG \& Mantovani A 1988 Induction of monocyte migration by recombinant macrophage colony stimulating factor. Journal of Immunology 141 575-579.

Wyckoff J, Wang W, Lin EY, Wang Y, Pixley F, Stanley ER, Graf T, Pollard JW, Segall J \& Condeelis J 2004 A paracrine loop between tumor cells and macrophages is required for tumor cell migration in mammary tumors. Cancer Research 64 7022-7029. (doi:10.1158/ 0008-5472.CAN-04-1449)

Received in final form 18 July 2013

Accepted 6 September 2013 http://erc.endocrinology-journals.org DOI: 10.1530/ERC-13-0198
(C) 2013 Society for Endocrinology Printed in Great Britain
Published by Bioscientifica Ltd. 